\title{
Recent Research Results on Groundwater Resources and Saltwater Intrusion in a Changing Environment
}

\author{
Maurizio Polemio ${ }^{1, *(D)}$ and Kristine Walraevens ${ }^{2}$ (D) \\ 1 CNR-IRPI, National Research Council-Research Institute for Geo-Hydrological Protection, \\ Via Amendola 122/I, 70126 Bari, Italy \\ 2 Laboratory for Applied Geology and Hydrogeology, Ghent University, Krijgslaan 281-S8, 9000 Gent, \\ Belgium; kristine.walraevens@ugent.be \\ * Correspondence: m.polemio@ba.irpi.cnr.it
}

Received: 15 May 2019; Accepted: 19 May 2019; Published: 29 May 2019

\begin{abstract}
This Special Issue presents the work of 30 scientists of 11 countries. It confirms that the impacts of global change, resulting from both climate change and increasing anthropogenic pressure, are huge on worldwide coastal areas (and very particularly on some islands of the Pacific Ocean), with highly negative effects on coastal groundwater resources, widely affected by seawater intrusion. Some improved research methods are proposed in the contributions: using innovative hydrogeological, geophysical, and geochemical monitoring; assessing impacts of the changing environment on the coastal groundwater resources in terms of quantity and quality; and using modelling, especially to improve management approaches. The scientific research needed to face these challenges must continue to be deployed by different approaches based on the monitoring, modeling, and management of groundwater resources. Novel and more efficient methods must be developed to keep up with the accelerating pace of global change.
\end{abstract}

Keywords: saltwater intrusion; groundwater resources; coastal aquifer; climate change; modelling; monitoring; salinization; water resources management

\section{Introduction}

The salinization of groundwater resources can be caused by natural phenomena and anthropogenic activities. If the global continental area of earth is considered, $16 \%$ is affected by groundwater salinization; seawater intrusion can be considered the prevalent phenomenon in terms of potential effects and risks [1]. Water and chemical fluxes, including nutrient loading, at the terrestrial/marine interface and across the sea floor provide an important linkage between terrestrial and marine environments.

Climate and global change impacts on the hydrological cycle [2], water resources, and ecosystems pose great challenges for global water and ecosystem management, especially where the ecological equilibria are strongly dependent on groundwater-surface water interaction [3]. The climate change scenarios require new and improved integrated tools for the assessment of climate change impacts on the hydrological cycle.

Coastal aquifers and ecosystems are currently under pressure globally from overexploitation and saltwater intrusion. Population growth and progressive gathering in coastal areas, climate change, and sea-level rise will increase this pressure and enhance the need for the protection and sustainable management of coastal groundwater resources and ecosystems for coastal communities in the future [4].

This Special Issue deals with hydrogeological, geophysical, and geochemical monitoring and characterization of the subsurface, involving the distribution of freshwater and saltwater; assessment of impacts resulting from the changing environment (both climate change and increasing anthropogenic pressure) on groundwater resources in coastal areas in terms of quantity and quality; and monitoring 
experiences and management approaches. This Special Issue presents the work of 30 scientists of 11 countries, located by the authors' place of work or study. The contributions have been grouped under three themes:

- impacts of the changing environment on the coastal groundwater resources;

- modelling of the freshwater-saltwater distribution;

- groundwater monitoring and management in coastal areas.

\section{Impacts of the Changing Environment on Coastal Groundwater Resources}

Oberle et al. [5], on the basis of monitoring data from Roi-Namur Island on Kwajalein Atoll, Marshall Islands, including electrical resistivity tomography (ERT) surveys, studied the impact of an island-overwash event, severe rainfall events, and tidal forcing of the freshwater lens on the groundwater resources of low-lying atoll islands. The overwash event was related to climate-induced local sea-level change, resulting in degradation in freshwater resources. Overwash events are likely to increase in severity in the future due to projected sea-level rises.

Stumm and Como [6] studied the saltwater intrusion using electromagnetic induction (EMI)-logging in the aquifer of southern Manhattan Island, New York. They reported that historical industrial pumping (22.7 million litres per day) early in the 20th century caused the development of several saltwater intrusion wedges. Although the pumping stopped more than 70 years ago, freshwater flow in the aquifer has been unable to push the saltwater back, due to limited recharge caused by impervious surfaces. They concluded that the glacial aquifer has had only a limited recovery from the past industrial exploitation.

Tal et al. [7] investigated the interrelationship between a multi-layered coastal aquifer at the southern Carmel plain in Israel, fish-ponds, and the sea using off-shore seismic surveying, on-land time-domain electromagnetic (TDEM) surveying, electrical conductivity (EC) profiles, hydrological field experiments, and groundwater levels. Using groundwater modelling, they showed that the exact location of the hydraulic connection between the confined aquifer unit and the sea (variable continuity of confining clay) played a significant role in the sensitivity of the aquifer unit to seawater intrusion. The geophysical methods they used helped to determine this location. They used another practical way to estimate this location, measuring the tidal amplitude in an observation well near the seashore. The authors suggested that these methods be used as managerial tools near the sea to avoid large seawater intrusion in response to impacts.

Mushtaha and Walraevens [8] quantified submarine groundwater discharge (SGD) in the Gaza Strip, Palestine, where overexploitation, seawater intrusion, and pollution by nutrients are putting the groundwater resources under high pressure. Using continuous radon measurements, they showed SGD to occur throughout the coast. High values of SGD were found in the south, and are probably related to the shallowness of the unconfined aquifer, while the lowest values of SGD were found in the middle of Gaza Strip, and they are probably related to the presence of Sabkhas. Considering that SGD would occur with the measured rates in a strip $100 \mathrm{~m}$ wide along the whole coast line, this results in a quantity of 38 million $\mathrm{m}^{3}$ of groundwater being discharged yearly to the Mediterranean Sea along the Gaza coast. This is accompanied by a yearly discharge of over 400 tons of nitrate and 250 tons of ammonium from groundwater to the Mediterranean Sea.

\section{Modelling of the Freshwater-Saltwater Distribution}

Yoon et al. [9] used data of tide level, rainfall, groundwater level, and interface to construct time series models based on an artificial neural network (ANN) and support vector machine (SVM). Their data were for the groundwater observatory on Jeju Island, South Korea. They used the "interface egg" [10], a monitoring probe which, thanks to its specific density, can float on the freshwater-saltwater interface. They showed that the SVM-based time series model was more accurate and stable than the ANN at the study site. 
Babu et al. [11] developed a methodology for regional- and well-scale modelling of an island freshwater lens based on a sharp interface approach. A quasi-three-dimensional finite element model was calibrated with freshwater thickness, where the interface was matched to the lower limit of the freshwater lens, using Tongatapu Island in the Kingdom of Tonga, a Pacific island nation, as a case study. The authors concluded that the application of a sharp interface groundwater model for real-world small islands is useful when dispersion models are challenging to implement due to insufficient data or computational resources.

Mabrouk et al. [12] assessed the situation in 2010 regarding the available fresh groundwater resources and evaluated future salinization in the Nile Delta Aquifer in Egypt, using a three-dimensional variable-density groundwater flow model coupled with salt transport with SEAWAT [13]. They examined six future scenarios that combine two driving forces: increased extraction and sea-level rise. The results showed that groundwater extraction has a greater impact on salinization of the Nile Delta Aquifer than sea-level rise, while the two factors combined cause the largest reduction of available fresh groundwater resources. The authors also determined the groundwater volumes of fresh water, brackish water, light brackish water, and saline water in the Nile Delta Aquifer. They identified the governorates that are most vulnerable to salinization.

\section{Groundwater Monitoring and Management in Coastal Areas}

Alberti et al. [14] considered the specific case of groundwater on small islands, with Nauru in the Pacific Ocean as an example, and warned for overexploitation of the thin freshwater lens and saltwater intrusion. They emphasized that the thin freshwater lens on small islands is an important resource to ensure the islands' future water security. But they emphasized that the most vulnerable aquifer systems in the world are present on small islands. Especially there, groundwater should be considered as a public and shared resource for present and future generations. The authors called for the State to directly assume the responsibility for extracting and distributing water from this vulnerable resource.

Alfarrah and Walraevens [15] studied coastal areas of arid and semi-arid regions, where the coastal aquifers are particularly at risk of saltwater intrusion, given the concentration of population along the coasts and the limited groundwater recharge. They discussed the case of Tripoli (Libya), where overexploitation has resulted in an impressive depression cone. Moreover, irrigation with nitrogen fertilizers and domestic sewage has led to high $\mathrm{NO}_{3}{ }^{-}$concentration and overall pollution of the resource.

\section{Conclusions}

The increasing population density along the coasts is observed at a global scale, together with the increase in groundwater abstraction, causing problems with groundwater salinity and quantity [16]. This Special Issue confirms that the impacts of global change, resulting from both climate change and increasing anthropogenic pressure, are huge on worldwide coastal areas, with highly negative effects on coastal groundwater resources, widely affected by seawater intrusion. The well-known specific vulnerability of islands in the Pacific Ocean is clearly illustrated by the case studies presented here.

The scientific research needed to face these challenges must continue to be deployed by different approaches based on the monitoring, modelling, and management of groundwater resources. Novel and more efficient methods must be developed to keep up with the accelerating pace of global change. New surveying geophysical methods and innovative monitoring tools and equipment offer opportunities for better accuracy, higher frequency, more simplicity, and reduced costs of seawater intrusion characterisation, while new modelling solutions improve our capacity to understand groundwater systems and to predict the future effects of global change.

The further development and integration of these novel approaches is an urgent and compelling challenge. The main objectives of research should be to define optimal groundwater management criteria and to improve the performance of large-scale mathematical models to assess the impacts of 
global change on groundwater resources, using long-term up-to-date monitoring tools both to calibrate and validate modelling results.

Funding: This research received no external funding.

Conflicts of Interest: The authors declare no conflict of interest.

\section{References}

1. IGRAC. Global Overview of Saline Groundwater Occurrence and Genesis; Report No. GP 2009-1; International Groundwater Resources Assessment Centre: Utrecht, The Netherlands, 2009.

2. Polemio, M.; Casarano, D. Climate change, drought and groundwater availability in southern Italy. Geol. Soc. Spec. Publ. 2008, 288, 39-51. [CrossRef]

3. De Giorgio, G.; Zuffianò, L.E.; Polemio, M. The role of the hydrogeological and anthropogenic factors on the environmental equilibrium of the Ugento Wetland (Southern Italy). Rend. Online Della Soc. Geol. Ital. 2019, $47,79-84$.

4. Langevin, C.; Sanford, W.; Polemio, M.; Povinec, P. Background and summary: A new focus on groundwater-seawater interactions. In New Focus on Groundwater-Seawater Interactions; Sanford, W., Langevin, C., Polemio, M., Povinec, P., Eds.; IAHS-AISH Publication: Oxford, UK, 2007; Volume 312, pp. 3-10.

5. Oberle, F.K.J.; Swarzenski, P.W.; Storlazzi, C.D. Atoll Groundwater Movement and Its Response to Climatic and Sea-Level Fluctuations. Water 2017, 9, 650. [CrossRef]

6. Stumm, F; Como, M.D. Delineation of Salt Water Intrusion through Use of Electromagnetic-Induction Logging: A Case Study in Southern Manhattan Island, New York. Water 2017, 9, 631. [CrossRef]

7. Tal, A.; Weinstein, Y.; Wollman, S.; Goldman, M.; Yechieli, Y. The Interrelations between a Multi-Layered Coastal Aquifer, a Surface Reservoir (Fish Ponds), and the Sea. Water 2018, 10, 1426. [CrossRef]

8. Mushtaha, A.M.; Walraevens, K. Quantification of Submarine Groundwater Discharge in the Gaza Strip. Water 2018, 10, 1818. [CrossRef]

9. Yoon, H.; Kim, Y.; Ha, K.; Lee, S.-H.; Kim, G.-P. Comparative Evaluation of ANN- and SVM-Time Series Models for Predicting Freshwater-Saltwater Interface Fluctuations. Water 2017, 9, 323. [CrossRef]

10. Kim, Y.; Yoon, H.; Kim, K.P. Development of a novel method to monitor the temporal change in the location of the fresh-saltwater interface and time series models for the prediction of the interface. Environ. Earth Sci. 2016, 75, 882-891. [CrossRef]

11. Babu, R.; Park, N.; Yoon, S.; Kula, T. Sharp Interface Approach for Regional and Well Scale Modeling of Small Island Freshwater Lens: Tongatapu Island. Water 2018, 10, 1636. [CrossRef]

12. Mabrouk, M.; Jonoski, A.; Oude Essink, G.H.P.; Uhlenbrook, S. Impacts of Sea Level Rise and Groundwater Extraction Scenarios on Fresh Groundwater Resources in the Nile Delta Governorates, Egypt. Water 2018, 10, 1690. [CrossRef]

13. Langevin, C.D. SEAWAT: A Computer Program for Simulation of Variable-Density Groundwater Flow and Multi-Species Solute and Heat Transport; U.S. Geological Survey Fact Sheet 2009-3047; USGS: Reston, VA, USA, 2009.

14. Alberti, L.; La Licata, I.; Cantone, M. Saltwater Intrusion and Freshwater Storage in Sand Sediments along the Coastline: Hydrogeological Investigations and Groundwater Modeling of Nauru Island. Water 2017, 9, 788. [CrossRef]

15. Alfarrah, N.; Walraevens, K. Groundwater Overexploitation and Seawater Intrusion in Coastal Areas of Arid and Semi-Arid Regions. Water 2018, 10, 143. [CrossRef]

16. Polemio, M. Monitoring and Management of Karstic Coastal Groundwater in a Changing Environment (Southern Italy): A Review of a Regional Experience. Water 2016, 8, 148. [CrossRef]

(C) 2019 by the authors. Licensee MDPI, Basel, Switzerland. This article is an open access article distributed under the terms and conditions of the Creative Commons Attribution (CC BY) license (http://creativecommons.org/licenses/by/4.0/). 